\title{
Cigarette flavors, package shape, and cigarette brand perceptions: an experiment among young Brazilian women
}

\author{
Farahnaz Islam, ${ }^{1}$ James F. Thrasher, ${ }^{2}$ André Szklo, ${ }^{3}$ Valeska Carvalho Figueiredo, ${ }^{4}$ \\ Cristina de Abreu Perez, ${ }^{5}$ Christine M. White, ${ }^{6}$ and David Hammond ${ }^{6}$
}

Suggested citation

Islam F, Thrasher JF, Szklo A, Figueiredo VC, Perez C, White CM, et al. Cigarette flavors, package shape, and cigarette brand perceptions: an experiment among young Brazilian women. Rev Panam Salud Publica. 2018;42:e5. https://doi.org/10.26633/RPSP.2018.5

ABSTRACT

Objective. In 2012, a new Brazilian regulation prohibited the use of flavor additives in tobacco products. To better understand the potential impact of this regulation, this study examines how flavor descriptors on cigarette packaging influence brand perceptions among young Brazilian women.

Methods. An online cross-sectional experiment was conducted with Brazilian women aged 16-26 ( $N=640: 182$ smokers and 458 nonsmokers) who rated 10 cigarette packages from one of three conditions: 1) branded packs; 2) packs with the same size, shape, and verbal descriptions as in condition 1, but without brand imagery (i.e., "plain pack"); and 3) packs from condition 2 but without brand descriptors (i.e., "plain pack, no descriptors"). Mixed-effects linear regression models were utilized to determine what associations that pack features (i.e., experimental condition; flavor descriptor ws. not; slim pack vs. not) had with participant ratings of nine characteristics, including appeal, taste, smoothness, and attributes of people who smoke the brand.

Results. Flavored branded packs were rated as more appealing, better tasting, and smoother than flavored plain packs with descriptors. Compared to flavored plain packs with descriptors, the same packs without descriptors were rated less positively on eight of the nine characteristics. Compared to nonsusceptible nonsmokers, susceptible nonsmokers rated flavored packs more positively on eight of the nine characteristics. Slim packs were rated more positively than regular packs on eight of the nine characteristics.

Conclusions. Slim packs and brands highlighting tobacco flavors appear to increase positive perceptions of tobacco products. Banning tobacco flavorings and slim packs may reduce the appeal of smoking for young Brazilian women, as well as for other vulnerable populations.

Keywords Tobacco; product packaging; flavoring agents; health policy; Brazil.
Cigarette flavors may promote tobacco use among youth by reducing the harshness of cigarette smoke, making cigarettes more appealing, and generating misperceptions of lesser harm compared to nonflavored cigarettes $(1,2)$. Consequently, prohibiting flavor additives and their descriptors may reduce tobacco use among youth.
Centro de Estudos sobre Tabaco e Saúde (CETAB), Escola Nacional de Saúde Pública Sergio Arouca, Fiocruz, Rio de Janeiro, Rio de Janeiro, Brazil.

5 Consultant, Rio de Janeiro, Rio de Janeiro, Brazil. 6 School of Public Health and Health Systems, University of Waterloo, Waterloo, Ontario, Canada.

2 Department of Health Promotion, Education and Behavior, Arnold School of Public Health,

\footnotetext{
University of South Carolina, Columbia, South Carolina, United States of America. Send correspondence to James F. Thrasher, at thrasher@

3 Department of Epidemiology, Instituto Nacional de Câncer, Rio de Janeiro, Rio de Janeiro, Brazil.
} 
In March 2012, Brazil's National Health Surveillance Agency (ANVISA) released a regulation that banned the sale of tobacco products with additives and flavors, with an exemption to allow for the replacement of sugars lost during the curing process (3). However, later that year, the National Industry Confederation filed a lawsuit in the Supreme Court, and implementation of the measure was suspended (4). Parallel to the judicial process, the tobacco industry applied pressure on ANVISA from late 2012 to early 2013 so that specific additives would be authorized in the country.

Facing strong pressure from economic interests opposed to the ban, in August 2013, ANVISA published a Normative Instruction that provisionally allowed 121 tobacco product additives for a period of 12 months, and established a working group of local and international experts to assess the additives used in tobacco products (4).

In August 2014, the ANVISA working group endorsed the original ban, while recommending that the list of banned additives be broadened to include sugar (5). To date, the Supreme Court has not yet issued a ruling, and implementation of the original regulation released in 2012 remains suspended. Activists and public health officials continue pushing for implementation by providing more evidence in this area to support the ban.

This article specifically analyzes the effects of flavor descriptors, as well as the effects of "slim" packaging that is designed to appeal to young women (6).

Youth perceptions of cigarettes are influenced by several aspects of tobacco product design and marketing, including the presence of flavors, such as menthol (7). The relatively higher prevalence of flavored cigarette use among youth aged 12-25 compared to adults suggests that flavors, including menthol, play a role in attracting new smokers (8). In 2011, menthol cigarettes accounted for nearly $11 \%$ of total cigarette sales in Brazil (9). A study based in Brazil found that $39 \%$ of females aged 13 to 15 selected a menthol cigarette as their preferred brand choice (10). Furthermore, some research suggests that the appeal of flavored tobacco is particularly powerful among high-school-age sensation seekers (i.e., those who actively seek out novel, exciting experiences) (11). Because sensation seeking predicts smoking behavior across sociocultural contexts
$(12,13)$, it is important to understand how tobacco marketing strategies may be particularly effective for sensation seekers, as well as for other youth who are susceptible to smoking.

Another prominent characteristic of tobacco product design that influences youth is cigarette packaging, including pack sizes and shapes. For example, a recent study found that pack structure (e.g., shape, size, type of openings) has a stronger influence than price, branding, or warning labels on perceptions of harm, taste, and intention to try (14). Youth, particularly females, perceive "slim" packs and "lipstick" sizes as more attractive, classier, and less harmful compared to standard packs (15). This is consistent with tobacco industry documents that highlight the appeal of slim packs for young women (6). In 2011, slim cigarette packs accounted for nearly $9 \%$ of total cigarette sales in Brazil. As a result, the tobacco industry made new investments in slim and superslim packaging (9).

Understanding the effects of flavorings and package design among young women is particularly important, given that the tobacco industry aggressively targets this population to expand the cigarette market (16). Young women's susceptibility to branding may make them particularly vulnerable to smoking initiation as a result of these marketing strategies (17). Although most forms of tobacco marketing are banned in Brazil, point-of-sale displays are still permitted, and thus cigarette packages are highly visible to consumers of all ages. One study (18) found that nearly $100 \%$ of retailers that sold flavored cigarettes displayed them inside the store, most frequently in or behind the cashier's area, or near sweets, snacks, or sugary drinks. In addition, other studies $(19,20)$ have shown that younger smokers (i.e., 24 years or under) are more likely than older smokers to notice tobacco advertising at point of sale. This highlights the reach and potential impact these displays and packages have on young smokers. Overall, cigarette packaging represents a critical form of tobacco marketing in Brazil, and it is a highly effective means of promoting smoking to young people.

The objective of this study was to assess the effects of flavor descriptors and slim packs on young women in Brazil. In particular, we tested the following hypotheses: 1) cigarette packs with flavor-related terms are associated with more favorable cigarette perceptions than packs without flavor-related terms; 2) sensation-seeking tendencies moderate the effects of flavor-related descriptors, such that the effects of flavor on pack ratings are stronger among those with higher than lower sensation-seeking tendencies; 3 ) among young women who do not currently smoke, packs with flavor-related descriptors are rated more favorably by those who are susceptible to smoking than by those who are not susceptible; and 4) "slim" cigarette packs are rated more favorably than packs with standard size and shapes.

\section{METHODS}

\section{Sample}

This study was conducted using data originally collected to determine how young Brazilian women perceive cigarette packaging that is progressively more "plain," after removing brand imagery (e.g., graphic design, color, logos, fonts) and descriptive words (e.g., flavors, color terms, shape) (21). Data from an online cross-sectional survey were collected in 2011 from a panel of consumers recruited through a commercial market research company (GMI) that purposefully assembles panel participants to represent key consumer segments in a range of countries. More information on the panel reach and data collection can be found online (www. gmi-mr.com). Panel members were sent invitations via email, asking them to participate in an online survey and informing them that the purpose of the study was to learn about people's opinions on cigarette packaging. Participants included 640 female smokers and nonsmokers from Brazil between 16 and 26 years of age. Further details about the study are published online (21).

\section{Protocol}

A between-subject design was used, with each participant randomly assigned to view and rate cigarette packages from one of three experimental conditions: 1) "branded packs" selected both from Brazil $(\mathrm{n}=4)$ and from other markets $(n=6)$, which included the original colors, designs, and wording, except with translations from English to Portuguese 
(for participants who could only read Portuguese); 2) "plain packs with descriptors," which had the same pack shape, size, and use of descriptive terms (e.g., gold, menthol, cherry, superslims) as in the branded pack condition, but with brand imagery removed and with a standardized font and text size across brands; or 3) "plain packs with no descriptors," which used the same packs as in the other plain pack condition but with descriptive terms removed.

Each condition included 10 packs, whose size and shape remained the same across conditions, with 5 standard packs and 5 packs that were "slim" (Figure 1). Flavor-related descriptors were included on half of the packs in the branded condition and the plain with descriptors condition. Comparable packs in the plain pack no descriptor condition had the same brand name, but the flavor-related descriptor was removed. In each condition, participants were shown color images of 10 cigarette packs, one at a time in random order, and were asked to rate each pack.

\section{Measures}

Measures were adapted from prior research on tobacco packaging and tobacco

\section{FIGURE 1. Cigarette pack images presented in each experimental condition in a study} of cigarette brand perceptions among Brazilian women, 2011

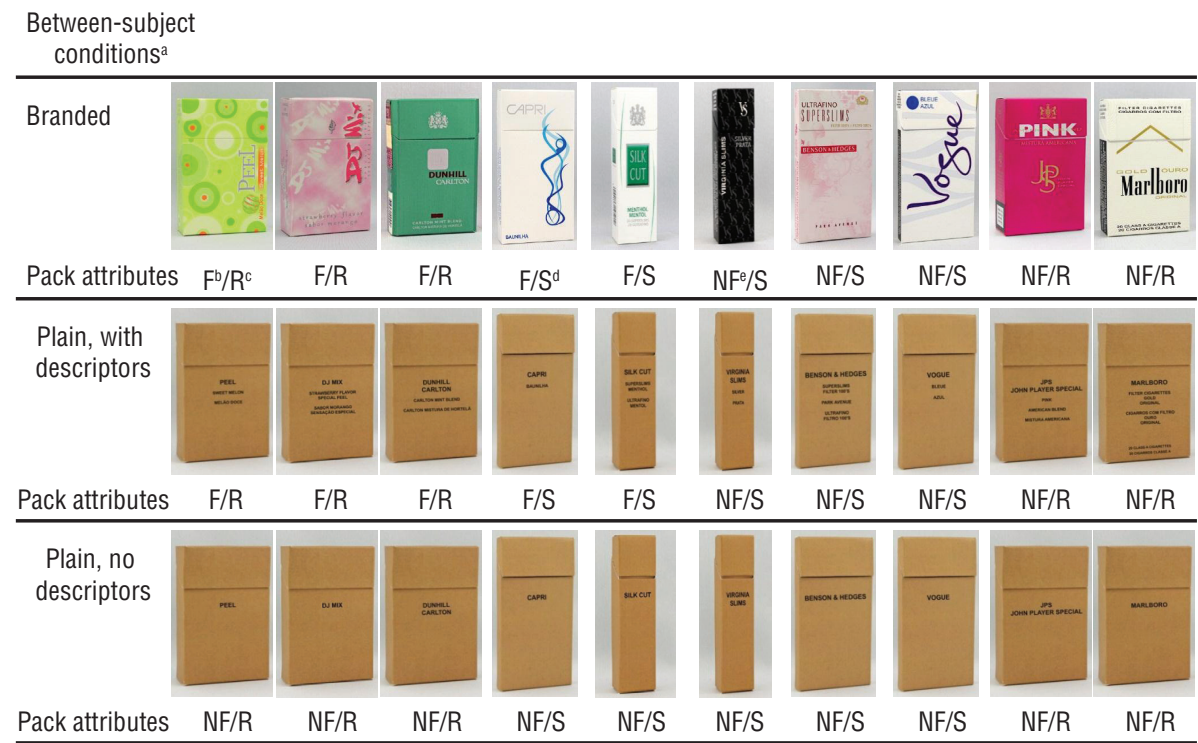

Source: Prepared by the authors from the study data

a Participants were randomly assigned to one of the three conditions and evaluated all 10 packs within that condition, in random order.

${ }^{\mathrm{b}} \mathrm{F}=$ Flavor descriptor.

${ }^{\mathrm{c}} \mathrm{R}=$ Regular-shaped packaging

d $S=$ Slim-shaped packaging.

e NF = No flavor descriptor.

policy (22). Two bilingual translators independently translated the online survey, with final translations based on a consensus approach (23). To ensure adequate comprehension and minimize response error, cognitive interviewing techniques were used to finalize the survey wording (24).

Pack ratings. Participants rated each pack "compared to other brands you can buy in stores" on the following brand characteristics: 1) brand appeal ("...how appealing is this brand of cigarettes?"); 2) taste (". . .how do you think these cigarettes would taste?"); 3) smoothness (". . .how smooth do you think these cigarettes would be on your throat?"); and 4) relative health risk (". . .would these cigarettes be. . . less/more harmful?"). A 5-point response scale was used, with desirable and undesirable characteristics balanced around a "no difference" response (e.g., "a lot less appealing"; " a little less appealing"; "no difference"; "a little more appealing"; "a lot more appealing"). Responses were coded from -2 to 2 , with higher values indicating more desirable attributes (more appealing, better taste, smoother, less harmful). Smoker image ratings were assessed by asking participants, "In your opinion, is someone who smokes this brand regularly 
"high" = completed postsecondary school, completed some graduate school, or completed graduate school). Due to convergence issues, only a three-category race variable was used in the models (i.e., "white"; "pardo" = brown; "other" = black, yellow, indigenous, multiracial, or other) (the distribution of all categories of race is provided later, in Table 1). Despite potential issues with validity in Brazil, this variable was included in the analysis because previous research with these data found associations between race and perceptions of relative health risk (21). Participants who indicated that they had smoked in the last 30 days were classified as current smokers, and the rest were classified as nonsmokers (27).

\section{Statistical analysis}

$F$ tests (analysis of variance) and Pearson chi-square tests were used to assess the differences between experimental conditions for sociodemographic and smoking-related variables. Means and standard errors were estimated for each outcome by experimental condition and whether the pack included a flavor-related descriptor.

Mixed-effects linear regression models were estimated to adjust for repeated observations at the individual level and to examine the main effects of flavor-related descriptors and pack shape (slim vs. not) on participant ratings for the four brand attributes and five smoker image characteristics, while adjusting for experimental condition and control variables. Mixed models were selected over linear models with only fixed effects since likelihood ratio tests comparing these models showed that mixed models had significantly better fit for all dependent variables except for the feminine smoker image characteristic. Within these mixed models, interactions were assessed by multiplying the flavor indicator and the variable of interest (e.g., sensation seeking, and education) and adding the resulting multiplicative term to the adjusted model, then

TABLE 1. Sociodemographic and smoking-related characteristics of Brazilian women age 16 to 26 who participated in study of cigarette brand perceptions, 2011, by category of package attribute

\begin{tabular}{|c|c|c|c|c|c|}
\hline Participant characteristic & $\begin{array}{l}\text { Total sample } \\
(\mathrm{N}=640)\end{array}$ & $\begin{array}{l}\text { Branded } \\
(n=214)\end{array}$ & $\begin{array}{l}\text { Plain with } \\
\text { descriptors } \\
(\mathrm{n}=208)\end{array}$ & $\begin{array}{l}\text { Plain with no } \\
\text { descriptors } \\
(\mathrm{n}=218)\end{array}$ & $\begin{array}{c}\text { Difference } \\
\text { between } \\
\text { groups }^{\mathrm{a}}\end{array}$ \\
\hline \multicolumn{6}{|l|}{ Age } \\
\hline Mean \pm standard deviation & $22.4 \pm 2.4$ & $22.4 \pm 2.3$ & $22.4 \pm 2.4$ & $22.4 \pm 2.5$ & $p=0.905$ \\
\hline \multicolumn{6}{|l|}{ Education } \\
\hline Low & $140(21.9 \%)$ & $40(18.8 \%)$ & $45(21.6 \%)$ & $55(25.1 \%)$ & $p=0.512$ \\
\hline Medium & $309(48.3 \%)$ & $104(48.8 \%)$ & $105(50.5 \%)$ & $100(45.7 \%)$ & \\
\hline High & $191(29.8 \%)$ & $69(32.4 \%)$ & $58(27.9 \%)$ & $64(29.2 \%)$ & \\
\hline \multicolumn{6}{|l|}{ Race } \\
\hline White & $401(62.9 \%)$ & $116(54.7 \%)$ & $135(65.2 \%)$ & $150(68.5 \%)$ & $p=0.000$ \\
\hline Pardo ${ }^{b}$ & $161(25.2 \%)$ & $69(32.5 \%)$ & $49(23.7 \%)$ & $43(19.6 \%)$ & \\
\hline Black & $32(5.0 \%)$ & $13(6.1 \%)$ & $7(3.4 \%)$ & $12(5.5 \%)$ & \\
\hline Multiracial & $23(3.6 \%)$ & $5(2.4 \%)$ & $11(5.3 \%)$ & $7(3.2 \%)$ & \\
\hline Yellow & $12(1.9 \%)$ & $5(2.4 \%)$ & $3(1.4 \%)$ & $4(1.8 \%)$ & \\
\hline Indigenous & $4(0.6 \%)$ & $0(0.0 \%)$ & $2(1.0 \%)$ & $2(0.9 \%)$ & \\
\hline Other & $5(0.8 \%)$ & $4(1.9 \%)$ & $0(0.0 \%)$ & $1(0.5 \%)$ & \\
\hline \multicolumn{6}{|l|}{ Smoking status } \\
\hline Smoker & $182(28.4 \%)$ & $60(28.2 \%)$ & $58(27.9 \%)$ & $64(29.2 \%)$ & $p=0.949$ \\
\hline Nonsmoker & $458(71.6 \%)$ & $153(71.8 \%)$ & $150(72.1 \%)$ & $155(70.8 \%)$ & \\
\hline \multicolumn{6}{|l|}{$\begin{array}{l}\text { Susceptibility } \\
\text { (nonsmokers only) }\end{array}$} \\
\hline Not susceptible & $263(57.4 \%)$ & $86(56.2 \%)$ & $78(52.0 \%)$ & $99(63.9 \%)$ & $p=0.104$ \\
\hline Susceptible & $195(42.6 \%)$ & $67(43.8 \%)$ & $72(48.0 \%)$ & $56(36.1 \%)$ & \\
\hline \multicolumn{6}{|l|}{ Sensation seeking } \\
\hline Mean \pm standard deviation & $2.4 \pm 0.7$ & $2.4 \pm 0.7$ & $2.4 \pm 0.7$ & $2.4 \pm 0.7$ & $p=0.997$ \\
\hline
\end{tabular}

removing it before assessing a different interaction. Chi-square tests were examined to assess the overall effect of the multiplicative term for the interaction variables. Models were then estimated to assess the combined effects of the pack condition and flavor-related descriptors by constructing dummy variables to indicate the six combinations that resulted from pack condition (i.e., branded; plain with descriptors; plain with no descriptors) and flavor-related descriptors. This included an indicator for packs in the plain no descriptor condition when a flavor-related descriptor was used on the analogous packs in the other conditions. Plain packs with flavor-related descriptors served as the reference group for ease of interpretation.

Finally, after limiting the analytic sample to never-smokers, models were reestimated using dummy variables to indicate the four combinations of smoking susceptibility and flavor-related descriptors, to compare the effects of flavor-related descriptors among susceptible and nonsusceptible nonsmokers. Sensitivity analyses were conducted using logistic regression models, where the dependent variable was categorized as 1 for favorable ratings and 0 for "no difference" or more negative ratings. The logistic models produced a pattern of results that was consistent with those from the linear regression models; hence, they were not included in this paper. All analyses were conducted in Stata version 14.0 software.

The study protocol received approval from the Office of Research Ethics at the University of Waterloo (Waterloo, Ontario, Canada). The information collected from participants are anonymized, unidentifiable, and kept in the strictest confidence in secure servers at GMI, the University of Waterloo, and the University of South Carolina.

\section{RESULTS}

The sociodemographic and smoking profile of the sample is shown in Table 1. The average age of participants was 22.4, and almost half $(48.3 \%)$ had moderate educational attainment. Most participants identified as white $(62.9 \%)$ and reported not smoking in the prior 30 days (71.6\%). Of the nonsmokers, $42.6 \%$ were considered susceptible to smoking cigarettes. No statistically significant differences were found across the three 
randomly allocated pack conditions, with the exception of race.

Mean ratings of brand characteristics for branded packs ranged from -0.01 to 0.63; plain packs with descriptors ranged from 0.02 to 0.49 ; and plain packs with no descriptors ranged from -0.05 to 0.26 . Mean ratings for smoker attributes for branded packs ranged from 0.13 to 0.38 ; plain packs with descriptors ranged from 0.09 to 0.35 ; and plain packs with no descriptors ranged from -0.04 to 0.25 (Table 2).

Mixed-effects models showed no statistically significant interactions between flavor-related descriptors and sensation seeking ( $p$ value range $=0.080$ to 0.969; results not shown) or education level ( $p$ value range $=0.33$ to 0.97 ; results not shown). Mixed-effects models were also estimated to test differences in ratings for specific contrasts between pack condition and flavor-related descriptors (Table 3). Compared to plain packs with flavor-related descriptors, branded packs with flavor-related descriptors were rated as significantly more appealing, smoother, and better tasting. When compared to plain packs with flavor-related descriptors, the same plain packs with these descriptors removed were rated as less favorable for all outcomes except for relative harm. Branded packs without flavor-related descriptors were rated as more appealing and less smooth, and taste ratings were significantly lower than plain packs with flavor-related descriptors. Plain packs with descriptors that were not flavor-related, and the corresponding packs with the descriptors removed, were rated as less smooth, and taste ratings were lower compared to ratings of plain packs with flavor-related descriptors.

In terms of smoker attribute ratings, branded packs without flavor-related descriptors were more likely to be rated as stylish and sophisticated but less likely to be rated as feminine compared to plain packs with flavor-related descriptors (Table 3). Plain packs with descriptors that were not flavor-related and the corresponding packs with the descriptor removed were less likely to be rated as feminine compared to plain packs with flavor-related descriptors. Slim packs were rated more favorably than standard sized packs across all outcomes except popularity.

Models were reestimated after limiting the analytic sample to never smokers, with ratings assessed for combinations of smoking susceptibility and the inclusion of a flavor-related descriptor on the pack (Table 4). In comparison to packs with flavor-related descriptors, susceptible nonsmokers rated packs without flavor-related descriptors as less appealing, more harmful, and less smooth; gave them lower taste ratings; and were less likely to rate them as feminine. Compared to nonsusceptible nonsmokers, susceptible nonsmokers rated packs with flavor-related descriptors more favorably for all attributes, except for perceived harm, which was of borderline significance $(p=0.08)$. Slim packs were rated as more favorable for all attributes, except for the lack of association with popularity.

\section{DISCUSSION}

This study indicates that cigarette brands featuring tobacco flavors increase favorable perceptions of tobacco among young Brazilian women. Plain packs with flavor-related descriptors were viewed more favorably than the corresponding packs without descriptors on eight of the nine characteristics assessed. Furthermore, among nonsmokers, cigarette packages with flavor-related descriptors were perceived more favorably among women who were considered susceptible to starting smoking. This is similar to other studies $(28,29)$ that show that flavored tobacco products make smoking more appealing to nonsmokers.

TABLE 2. Brand characteristics and smoker attributes, according to Brazilian women $(\mathrm{N}=640)$ participating in study of cigarette brand perceptions, by pack condition, flavor, and pack shape, with mean and standard deviation (SD), 2011

\begin{tabular}{|c|c|c|c|c|c|c|c|c|c|c|}
\hline \multirow{3}{*}{ Pack attributes } & & \multicolumn{4}{|c|}{ Brand characteristic } & \multicolumn{5}{|c|}{ Smoker attribute } \\
\hline & & Appeal & Taste & Harm & Smooth & Feminine & Style & Popular & Sophisticated & Slim \\
\hline & & $\begin{array}{l}\text { Mean } \\
(\mathrm{SD})\end{array}$ & $\begin{array}{l}\text { Mean } \\
(\mathrm{SD})\end{array}$ & $\begin{array}{l}\text { Mean } \\
(\mathrm{SD})\end{array}$ & $\begin{array}{l}\text { Mean } \\
(\mathrm{SD})\end{array}$ & $\begin{array}{l}\text { Mean } \\
(\mathrm{SD})\end{array}$ & $\begin{array}{l}\text { Mean } \\
(\mathrm{SD})\end{array}$ & $\begin{array}{l}\text { Mean } \\
(\mathrm{SD})\end{array}$ & $\begin{array}{l}\text { Mean } \\
(\mathrm{SD})\end{array}$ & $\begin{array}{l}\text { Mean } \\
(\mathrm{SD})\end{array}$ \\
\hline Condition & Flavor & & & & & & & & & \\
\hline \multirow[t]{2}{*}{ Branded } & Yes & $\begin{array}{c}0.58 \\
(1.24)\end{array}$ & $\begin{array}{c}0.63 \\
(1.07)\end{array}$ & $\begin{array}{l}-0.01 \\
(0.77)\end{array}$ & $\begin{array}{c}0.50 \\
(0.92)\end{array}$ & $\begin{array}{c}0.30 \\
(0.70)\end{array}$ & $\begin{array}{c}0.34 \\
(0.67)\end{array}$ & $\begin{array}{c}0.16 \\
(0.64)\end{array}$ & $\begin{array}{c}0.25 \\
(0.68)\end{array}$ & $\begin{array}{r}0.13 \\
(0.46)\end{array}$ \\
\hline & No & $\begin{array}{c}0.61 \\
(1.20)\end{array}$ & $\begin{array}{c}0.32 \\
(0.96)\end{array}$ & $\begin{array}{c}0.04 \\
(0.72)\end{array}$ & $\begin{array}{c}0.18 \\
(0.86)\end{array}$ & $\begin{array}{c}0.26 \\
(0.78)\end{array}$ & $\begin{array}{c}0.38 \\
(0.67)\end{array}$ & $\begin{array}{c}0.17 \\
(0.65)\end{array}$ & $\begin{array}{c}0.35 \\
(0.66)\end{array}$ & $\begin{array}{r}0.20 \\
(0.50)\end{array}$ \\
\hline \multirow[t]{2}{*}{ Plain with descriptors } & Yes & $\begin{array}{c}0.31 \\
(1.18)\end{array}$ & $\begin{array}{c}0.49 \\
(1.05)\end{array}$ & $\begin{array}{c}0.02 \\
(0.66)\end{array}$ & $\begin{array}{c}0.34 \\
(0.86)\end{array}$ & $\begin{array}{c}0.35 \\
(0.69)\end{array}$ & $\begin{array}{c}0.26 \\
(0.66)\end{array}$ & $\begin{array}{c}0.12 \\
(0.61)\end{array}$ & $\begin{array}{c}0.22 \\
(0.64)\end{array}$ & $\begin{array}{r}0.13 \\
(0.50)\end{array}$ \\
\hline & No & $\begin{array}{c}0.24 \\
(1.05)\end{array}$ & $\begin{array}{c}0.12 \\
(0.81)\end{array}$ & $\begin{array}{c}0.04 \\
(0.68)\end{array}$ & $\begin{array}{c}0.03 \\
(0.79)\end{array}$ & $\begin{array}{c}0.09 \\
(0.77)\end{array}$ & $\begin{array}{c}0.26 \\
(0.67)\end{array}$ & $\begin{array}{c}0.10 \\
(0.63)\end{array}$ & $\begin{array}{c}0.24 \\
(0.67)\end{array}$ & $\begin{array}{r}0.16 \\
(0.52)\end{array}$ \\
\hline \multirow[t]{2}{*}{$\begin{array}{l}\text { Plain with no } \\
\text { descriptors }\end{array}$} & $Y_{e s}^{a}$ & $\begin{array}{l}-0.05 \\
(1.10)\end{array}$ & $\begin{array}{l}-0.02 \\
(0.87)\end{array}$ & $\begin{array}{l}-0.04 \\
(0.62)\end{array}$ & $\begin{array}{l}-0.05 \\
(0.78)\end{array}$ & $\begin{array}{l}-0.04 \\
(0.68)\end{array}$ & $\begin{array}{c}0.06 \\
(0.66)\end{array}$ & $\begin{array}{c}0.03 \\
(0.62)\end{array}$ & $\begin{array}{c}0.02 \\
(0.67)\end{array}$ & $\begin{array}{c}0.07 \\
(0.48)\end{array}$ \\
\hline & No & $\begin{array}{c}0.26 \\
(1.12)\end{array}$ & $\begin{array}{c}0.15 \\
(0.90)\end{array}$ & $\begin{array}{l}-0.01 \\
(0.63)\end{array}$ & $\begin{array}{l}-0.01 \\
(0.84)\end{array}$ & $\begin{array}{c}0.04 \\
(0.76)\end{array}$ & $\begin{array}{c}0.25 \\
(0.67)\end{array}$ & $\begin{array}{c}0.16 \\
(0.65)\end{array}$ & $\begin{array}{c}0.19 \\
(0.68)\end{array}$ & $\begin{array}{r}0.16 \\
(0.50)\end{array}$ \\
\hline \multicolumn{11}{|l|}{ Pack shape } \\
\hline Not slim & & $\begin{array}{c}0.25 \\
(1.20)\end{array}$ & $\begin{array}{c}0.26 \\
(1.02)\end{array}$ & $\begin{array}{c}0.03 \\
(0.71)\end{array}$ & $\begin{array}{c}0.13 \\
(0.90)\end{array}$ & $\begin{array}{c}0.07 \\
(0.76)\end{array}$ & $\begin{array}{c}0.18 \\
(0.68)\end{array}$ & $\begin{array}{c}0.11 \\
(0.64)\end{array}$ & $\begin{array}{c}0.12 \\
(0.68)\end{array}$ & $\begin{array}{r}0.09 \\
(0.47)\end{array}$ \\
\hline Slimb & & $\begin{array}{c}0.41 \\
(1.14)\end{array}$ & $\begin{array}{c}0.31 \\
(0.92)\end{array}$ & $\begin{array}{l}-0.01 \\
(0.66)\end{array}$ & $\begin{array}{c}0.21 \\
(0.84)\end{array}$ & $\begin{array}{c}0.26 \\
(0.72)\end{array}$ & $\begin{array}{c}0.34 \\
(0.66)\end{array}$ & $\begin{array}{c}0.14 \\
(0.63)\end{array}$ & $\begin{array}{c}0.31 \\
(0.66)\end{array}$ & $\begin{array}{r}0.20 \\
(0.50)\end{array}$ \\
\hline
\end{tabular}

Source: Prepared by the authors from the study data.

${ }^{\text {a }}$ Flavor descriptor not included on the pack, but pack shape, size, and brand name equivalent to plain with flavor descriptors.

${ }^{b}$ Pack shape is more slender than a regular-shaped pack. Slim with regard to smoker attributes refers to whether the type of smoker who would use this brand is slim or not. 
TABLE 3. Mixed linear models of brand characteristics and smoker attributes according to Brazilian women ( $\mathrm{N}=640)$ participating in study of cigarette brand perceptions, by pack condition, flavor descriptors, and pack shape, 2011ª

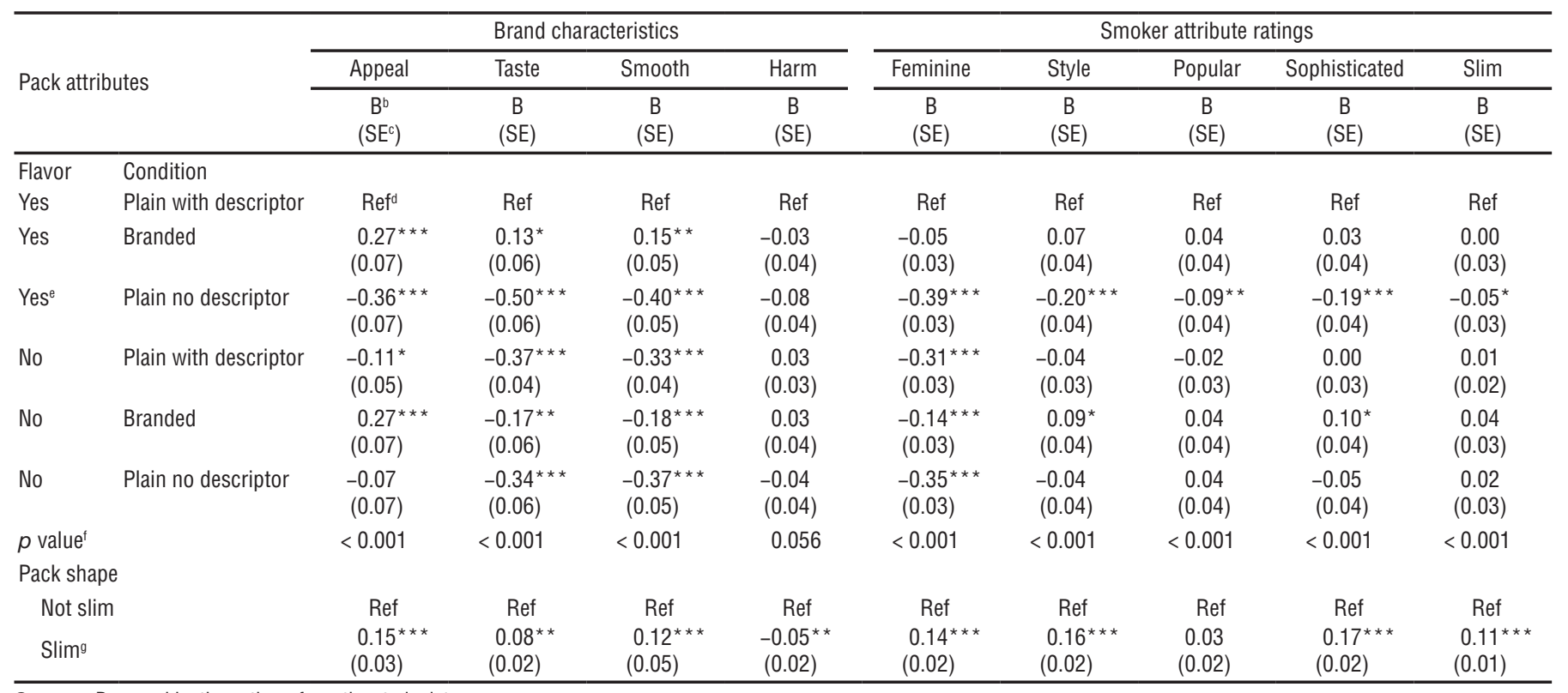

Source: Prepared by the authors from the study data.

${ }^{a}$ Model controlled for age, education, race, smoking (smoker, susceptible nonsmokers, nonsusceptible nonsmoker), sensation seeking, and the other variables shown in the table; ${ }^{\star}=p<$ $.05,{ }^{* *}=p<.01,{ }^{* * *}=p<.001$.

${ }^{\mathrm{b}} \mathrm{B}=$ coefficient estimate.

${ }^{\mathrm{C}} \mathrm{SE}=$ standard error.

${ }^{\mathrm{d}} \mathrm{Ref}=$ reference group.

${ }^{\text {e }}$ Flavor descriptor not included on the pack, but pack shape, size, and brand name equivalent to plain with flavor descriptors.

${ }^{\dagger}$ The $p$ value is from chi-square tests.

${ }^{g}$ Pack shape is more slender than a regular-shaped pack. Slim with regard to smoker attributes refers to whether the type of smoker who would use this brand is slim or not.

TABLE 4. Mixed linear models of brand characteristics and smoker attributes according to current nonsmoking Brazilian women $(n=458)$ participating in study of cigarette brand perceptions, by smoking susceptibility, flavor descriptors, and pack shape, 2011

\begin{tabular}{|c|c|c|c|c|c|c|c|c|c|c|}
\hline & & \multicolumn{4}{|c|}{ Brand characteristics } & \multicolumn{5}{|c|}{ Smoker attribute ratings } \\
\hline \multicolumn{2}{|c|}{ Participant and pack attributes } & Appeal & Taste & Smooth & Harm & Feminine & Style & Popular & Sophisticated & Slim \\
\hline & & $\begin{array}{c}\mathrm{B}^{\mathrm{b}} \\
\left(\mathrm{SE}^{\mathrm{c}}\right)\end{array}$ & $\begin{array}{c}B \\
(\mathrm{SE})\end{array}$ & $\begin{array}{c}\text { B } \\
(\mathrm{SE})\end{array}$ & $\begin{array}{c}\mathrm{B} \\
(\mathrm{SE})\end{array}$ & $\begin{array}{c}\text { B } \\
(\mathrm{SE})\end{array}$ & $\begin{array}{c} \\
\text { (SE) }\end{array}$ & $\begin{array}{c}B \\
(\mathrm{SE})\end{array}$ & $\begin{array}{c}\text { B } \\
(\mathrm{SE})\end{array}$ & $\begin{array}{c}B \\
(\mathrm{SE})\end{array}$ \\
\hline Pack flavor & $\begin{array}{l}\text { Susceptible to } \\
\text { smoke }\end{array}$ & & & & & & & & & \\
\hline Yes & Yes & $\operatorname{Ref}^{d}$ & Ref & Ref & Ref & Ref & Ref & Ref & Ref & Ref \\
\hline Yes & No & $\begin{array}{l}-0.21^{* *} \\
(0.07)\end{array}$ & $\begin{array}{l}-0.18^{\star *} \\
(0.06)\end{array}$ & $\begin{array}{l}-0.15^{\star *} \\
(0.05)\end{array}$ & $\begin{array}{c}0.08 \\
(0.04)\end{array}$ & $\begin{array}{c}-0.12^{\star} \\
(0.04)\end{array}$ & $\begin{array}{l}-0.15^{\star \star} \\
(0.04)\end{array}$ & $\begin{array}{l}-0.12^{\star *} \\
(0.04)\end{array}$ & $\begin{array}{l}-0.11^{\star} \\
(0.04)\end{array}$ & $\begin{array}{l}-0.09 * * \\
(0.03)\end{array}$ \\
\hline $\mathrm{No}^{\mathrm{e}}$ & Yes & $\begin{array}{c}-0.13^{\star} \\
(0.06)\end{array}$ & $\begin{array}{l}-0.44^{\star \star \star} \\
(0.04)\end{array}$ & $\begin{array}{l}-0.37^{\star \star \star} \\
(0.04)\end{array}$ & $\begin{array}{l}0.09 * * \\
(0.03)\end{array}$ & $\begin{array}{l}-0.22^{\star \star \star} \\
(0.04)\end{array}$ & $\begin{array}{c}-0.04 \\
(0.03)\end{array}$ & $\begin{array}{c}-0.02 \\
(0.03)\end{array}$ & $\begin{array}{c}0.03 \\
(0.03)\end{array}$ & $\begin{array}{c}0.02 \\
(0.02)\end{array}$ \\
\hline No & No & $\begin{array}{l}-0.30^{\star * *} \\
(0.07)\end{array}$ & $\begin{array}{l}-0.55^{\star \star \star} \\
(0.06)\end{array}$ & $\begin{array}{l}-0.48^{* * *} \\
(0.05)\end{array}$ & $\begin{array}{c}0.10^{*} \\
(0.04)\end{array}$ & $\begin{array}{l}-0.30 * * * \\
(0.04)\end{array}$ & $\begin{array}{l}-0.17^{\star \star \star} \\
(0.04)\end{array}$ & $\begin{array}{l}-0.14^{\star \star *} \\
(0.04)\end{array}$ & $\begin{array}{l}-0.13^{\star \star} \\
(0.04)\end{array}$ & $\begin{array}{c}-0.07^{\star} \\
(0.03)\end{array}$ \\
\hline$p$ value $^{f}$ & & $<0.001$ & $<0.001$ & $<0.001$ & 0.028 & $<0.001$ & $<0.001$ & 0.001 & $<0.001$ & 0.002 \\
\hline \multicolumn{11}{|l|}{ Pack shape } \\
\hline Not slim & & Ref & Ref & Ref & Ref & Ref & Ref & Ref & Ref & Ref \\
\hline Slim $^{g}$ & & $\begin{array}{l}0.16^{\star \star \star} \\
(0.03)\end{array}$ & $\begin{array}{l}0.09 * * * \\
(0.03)\end{array}$ & $\begin{array}{l}0.08^{* * *} \\
(0.02)\end{array}$ & $\begin{array}{l}-0.05^{\star \star} \\
(0.02)\end{array}$ & $\begin{array}{l}0.19 * * * \\
(0.02)\end{array}$ & $\begin{array}{l}0.15^{\star \star *} \\
(0.02)\end{array}$ & $\begin{array}{c}0.01 \\
(0.02)\end{array}$ & $\begin{array}{l}0.17^{\star \star \star} \\
(0.02)\end{array}$ & $\begin{array}{l}0.10^{\star \star *} \\
(0.10)\end{array}$ \\
\hline
\end{tabular}

Source: Prepared by the authors from the study data.

a Model controlled for age, education, race, sensation seeking, experimental condition, and the variables shown in the table; ${ }^{*}=p<.05,{ }^{* *}=p<.01,{ }^{* * *}=p<.001$.

${ }^{\mathrm{b}} \mathrm{B}=$ coefficient estimate.

${ }^{\mathrm{S}} \mathrm{SE}=$ standard error.

${ }^{\mathrm{d}}$ Ref $=$ reference group

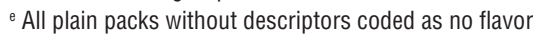

${ }^{\dagger}$ The $p$ value is from chi-square tests.

${ }^{g}$ Pack shape is more slender than a regular-shaped pack. Slim with regard to smoker attributes refers to whether the type of smoker who would use this brand is slim or not. 
Unlike other research (11), we did not find that sensation seeking moderated flavor-related descriptor effects, perhaps because the predictive power of sensation seeking on smoking behavior is stronger among younger populations. Overall, however, our findings suggest that banning tobacco flavor additives and their descriptors may reduce the attraction of smoking for young Brazilian women.

While implementation of the Brazilian regulation has been delayed through legal action, other jurisdictions and entities, such as the European Union (30), have adopted regulations to prohibit flavors, partly because of their effects on youth. Our study suggests that specific language banning flavor-related descriptors may be necessary. In Australia, where a ban on flavor-related descriptors is combined with "plain" packaging, the industry has actively introduced a great range of general descriptive terms to hint at flavors (e.g., green refers to menthol) (31).

This study also indicates that banning slim packs may reduce the appeal of smoking for young Brazilian women. Respondents rated "slim" packs more favorably than standard-sized packs across all characteristics assessed, although ratings for popularity were only statistically significant in the main effects model. Consistent with other studies, cigarettes from slim packs were perceived as less harmful than those from standard packs $(6,14,15)$. This finding indicates that slim packaging promotes misperceptions of relative risk, since all cigarettes are equally harmful. As such, slim packs violate key tenants of the World Health Organization's Framework Convention on Tobacco Control, including bans on marketing strategies that promote misunderstandings of reduced harm for some types of cigarettes (32). Indeed, the appeal of slim packaging design led Australia to restrict the shape and size of

1. Feirman SP, Lock D, Cohen JE, Holtgrave $\mathrm{DR}, \mathrm{Li}$ T. Flavored tobacco products in the United States: a systematic review assessing use and attitudes. Nicotine Tob Res. 2016;18(5):739-49.

2. Lewis MJ, Wackowski O. Dealing with an innovative industry: a look at flavored cigarettes promoted by mainstream brands. Am J Public Health. 2006;96(2):244-51. packs in its "plain" packaging regulations, which were implemented in 2012. Early research suggests this measure has had a positive impact, particularly in terms of reducing the appeal of cigarettes among youth (33).

This study had some potential limitations. The study was not originally designed to evaluate flavors or slim packs. However, the number of stimuli was generally balanced within experimental conditions with regard to the number of packs with flavor-related descriptors vs. other types of descriptors and slim vs. standard pack shapes and sizes. To further isolate the effects of these specific packaging elements, future research might consider integration of additional stimuli (e.g., standard-sized packs with branding elements from slim packs), while also integrating other pack characteristics that influence perceptions and use, such as price. Furthermore, participants were shown images of packs through an online interface, which may not adequately simulate naturalistic exposure to tangible packaging. However, studies examining other aspects of tobacco packaging (e.g., cigarette warning labels) have produced consistent results across experiments that present images of warnings on computer screens (34) or on physical cigarette packs (35), as well as when assessing consumer responses after warnings are implemented on cigarette packaging (36). Furthermore, the protocols were adapted from those used by the tobacco industry itself (6). Hence, biases introduced by the stimulus presentation mode appear unlikely to have seriously influenced results.

This study involved collection of data from an online panel of consumers with unknown generalizability. However, almost half of Brazilians have access to the Internet (37), including $70 \%$ of those 16 to 24 years old (38). The analytic sample had higher educational attainment than

\section{REFERENCES}

3. Agência Nacional de Vigilância sanitária. Resolução - RDC no 14 , de 15 de março de 2012. Diário Oficial da União Seção 1. 2012; $\mathrm{N}^{\circ}$ 53:176.

4. Turci SRB, Figueiredo VC, da Costa e Silva VL. A regulação de aditivos que conferem sabor e aroma aos produtos derivados do tabaco no Brasil. Cad Ibero-Amer Dir Sanit. 2014;3(1):44-67. the general population of Brazil, in which smoking prevalence is higher amongst groups with relatively lower educational attainment. The fact that we found no evidence of moderation by education may just be a result of low recruitment in the lower education segment. Also, future studies could consider defining female as a "negative" response, as some women may perceive femininity as a negative trait. Finally, this study was conducted prior to the legal challenges regarding cigarette flavor bans in Brazil. Media attention surrounding these legal challenges may have influenced young people's perceptions of flavored cigarettes and packs, but additional research is necessary to understand the direction of influence on their perceptions or behavior.

In spite of these limitations, this study adds to the evidence base that consistently shows that flavor additives, their descriptors, and slim packs are attractive to young women, promote misperceptions of reduced risk, and are therefore likely to promote tobacco use. Jurisdictions that aim to prevent tobacco use among youth and young adults, particularly women, should consider banning both flavors and the use of flavor-related descriptors in brand names, as well as restricting the size and shape of cigarette packs.

Acknowledgments. The authors thank Said Bichara, Renato Costa, Samantha Daniel, Matt Grey, Paula Johns, and Jessica Reid for their technical and translation assistance with this study and article.

\section{Conflicts of interest. None.}

Disclaimer. Authors hold sole responsibility for the views expressed in the manuscript, which may not necessarily reflect the opinion or policy of the RPSP/ PAJPH or PAHO.
5. Working Group on Tobacco Additives Report of the Working Group on Tobacco Additives. Rio de Janeiro, Brazil, August 2014. Rio de Janeiro: Working Group on Tobacco Additives; 2014.

6. Kotnowski K, Hammond D. The impact of cigarette pack shape, size and opening: evidence from tobacco company documents. Addiction. 2013;108(9):1658-68. 
7. Anderson S. Marketing of menthol cigarettes and consumer perceptions: a review of tobacco industry documents. Tob Control. 2011;20(S2):ii20-8.

8. Giovino G, Villanti A, Mowery P, Sevilimedu V, Niaura R, Vallone D, et al. Differential trends in cigarette smoking in the USA: Is menthol slowing progress? Tob Control. 2015;24(1):28-37.

9. Euromonitor International. Tobacco. London: Euromonitor Passport Database; 2014.

10. Figueiredo VC, Costa e Silva VL, Casado L, Masson E, Cavalcante T, Almeida LM. Use of flavored cigarettes among Brazilian adolescents: a step toward nicotine addiction? Poster presented at the 15th World Conference on Tobacco or Health, Singapore, March 2012.

11. Manning KC, Kelly KJ, Comello ML. Flavoured cigarettes, sensation seeking and adolescents' perceptions of cigarette brands. Tob Control. 2009;18(6):459-65.

12. Thrasher JF, Sargent JD, Huang L, ArilloSantillan E, Dorantes-Alonso A, PerezHernandez R. Does film smoking promote youth smoking in middle-income countries?: a longitudinal study among Mexican adolescents. Cancer Epidemiol Biomarkers Prev. 2009;18(12):3444-50.

13. Mejia R, Perez A, Pena L, Kollath-Cattano C, Morello P, Braun S, et al. Smoking in movies and adolescent smoking initiation: a longitudinal study among Argentinian adolescents. Journal Pediatr. 2017;180:222-8.

14. Kotnowski K, Fong GT, Gallopel-Morvan $\mathrm{K}$, Islam T, Hammond D. The impact of cigarette packaging design among young females in Canada: findings from a discrete choice experiment. Nicotine Tob Res. 2016;18(5):1348-56.

15. Moodie C, Ford A. Young adult smokers' perceptions of cigarette pack innovation, pack colour and plain packaging. Australas Mark J. 2011;19(3):174-80.

16. Carpenter CM, Wayne GF, Connolly GN. Designing cigarettes for women: new findings from the tobacco industry documents. Addiction. 2005;100(6):837-51.

17. U.S. Department of Health and Human Services. Factors influencing tobacco use among women. Atlanta: U.S. Department of Health and Human Services, Public Health Service, Centers for Disease Control and Prevention, National Center for Chronic Disease Prevention and Health Promotion, Office on Smoking and Health; 2001.

18. Institute for Global Tobacco Control. Technical report on flavored cigarettes at the point-of-sale in Latin America: availability and marketing around primary and secondary schools in five countries. Baltimore: Johns Hopkins Bloomberg School of Public Health; 2017.

19. Instituto Nacional de Câncer. Global adult tobacco survey Brazil 2008. Rio de Janeiro: INCA, Ministério da Saúde; 2010.

20. Instituto Brasileiro de Geografia e Estatística. Pesquisa Nacional de Saúde 2013. Percepção do estado de saúde, estilos de vida e doenças crônicas. Brasil, Grandes Regiões e Unidades da Federação. Rio de Janeiro: IBGE; 2014.

21. White CM, Hammond D, Thrasher JF, Fong GT. The potential impact of plain packaging of cigarette products among Brazilian young women: an experimental study. BMC Public Health. 2012;12:737.

22. Hammond D, Doxey J, Daniel S, BansalTravers M. Impact of female-oriented cigarette packaging in the United States. Nicotine Tob Res. 2011;13(7):579-88.

23. Harkness J, Pennell B-E, Schoua-Glusberg A. Survey questionnaire translation and assessment. In: Presser SR, Jennifer M, Couper MP, Lessler JT, Martin E, Martin J, et al., eds. Methods for testing and evaluating survey questionnaires. Hoboken, New Jersey: John Wiley \& Sons, Inc.; 2004:453-73.

24. Willis GB. Cognitive interviewing: a tool for improving questionnaire design. Thousand Oaks, California: Sage Publications; 2004.

25. Hoyle RH, Stephenson MT, Palmgreen P, Lorch EP, Donohew RL. Reliability and validity of a brief measure of sensation seeking. Pers Individ Differ. 2002;32(3):401-14.

26. Pierce JP, Choi WS, Gilpin EA, Farkas AJ, Merritt RK. Validation of susceptibility as a predictor of which adolescents take up smoking in the United States. Health Psychol. 1996;15(5):355-61.

27. Kann L, Kinchen S, Shanklin SL, Flint KH, Kawkins J, Harris WA, et al. Youth risk behavior surveillance-United States, 2013. MMWR Surveill Summ. 2014;63(Suppl 4): $1-168$.

28. Connolly GN, Behm I, Osaki Y, Wayne GF. The impact of menthol cigarettes on smoking initiation among non-smoking young females in Japan. Int J Environ Res Public Health. 2011;8(1):1-14.

29. Klausner K. Menthol cigarettes and smoking initiation: a tobacco industry perspective. Tob Control. 2011;20(S2):ii12-9.

30. The European Parliament, The Council of the European Union. Directive 2014/40/ EU of the European Parliament and of the Council of 3 April 2014 on the approximation of the laws, regulations and administrative provisions of the Member States concerning the manufacture, presentation and sale of tobacco and related products and repealing Directive 2001/37/EC (1). Off J Eur Union. 2014;57 (L 127):1-38.

31. Scollo M, Occleston J, Bayly M, Lindorff K, Wakefield M. Tobacco product developments coinciding with the implementation of plain packaging in Australia. Tob Control. 2015;24(e1):e116-22.

32. World Health Organization. Guidelines for implementation of Article 13 of the WHO Framework Convention on Tobacco Control (tobacco advertising, promotion \& sponsorship). Geneva: WHO; 2009.

33. Chapman S, Freeman B. Removing the emperor's clothes: Australia and tobacco plain packaging. Sydney: Sydney University Press; 2014.

34. Hammond D, Thrasher J, Reid JL, Driezen P, Boudreau C, Santillan EA. Perceived effectiveness of pictorial health warnings among Mexican youth and adults: a population-level intervention with potential to reduce tobacco-related inequities. Cancer Causes Control. 2012;23 Suppl 1:57-67.

35. Thrasher JF, Arillo-Santillan E, Villalobos V, Perez-Hernandez R, Hammond D, Carter J, et al. Can pictorial warning labels on cigarette packages address smoking-related health disparities? Field experiments in Mexico to assess pictorial warning label content. Cancer Causes Control. 2012;23 Suppl 1:69-80.

36. Huang L-L, Thrasher JF, Reid JL, Hammond D. Predictive and external validity of a pre-market study to determine the most effective pictorial health warning label content for cigarette packages. Nicotine Tob Res. 2016;18(5):1376-81.

37. International Telecommunications Union. Percentage of population using the internet in Brazil from 2000 to 2015. Available from: https://www.statista.com/statistics / 209106/number-of-internet-usersper-100-inhabitants-in-brazil-since-2000/ Accessed on 21 July 2016.

38. Comitê Gestor da Internet no Brasil. TIC kids online Brasil 2012: pesquisa sobre o uso da internet por crianças e adolescentes no Brasil. São Paulo: Comitê Gestor da Internet no Brasil, 2013.

Manuscript received on 21 July 2016. Revised version accepted for publication on 9 June 2017. 
RESUMEN

\section{Los sabores de cigarrillos, la forma del paquete y las percepciones de las marcas de cigarrillos: un experimento entre las jóvenes brasileñas}

Palabras clave
Objetivo. En 2012, una nueva regulación brasileña prohibió el uso de aditivos de sabor en los productos de tabaco. Para comprender mejor el impacto potencial de esta regulación, este estudio examina cómo los descriptores de sabor en los envases de cigarrillos influyen en las percepciones de marca entre las jóvenes brasileñas.

Métodos. Se realizó un estudio transversal, en línea con mujeres brasileñas de entre 16 y 26 años ( $\mathrm{N}=640$ : 182 fumadores y 458 no fumadores) que calificaron 10 paquetes de cigarrillos de acuerdo a una de las siguientes condiciones: 1) paquetes de marca; 2) paquetes con el mismo tamaño, forma y descripciones verbales que en la condición 1, pero sin imágenes de marca (es decir, "paquete simple"); y 3) paquetes de la condición 2 pero sin descriptores de marca (es decir, "paquete simple, sin descriptores"). Se utilizaron modelos de regresión lineal de efectos mixtos para determinar qué asociación existía entre las diferentes condiciones (es decir, condición experimental, descriptor de sabor vs. no, paquete delgado vs. no) con las calificaciones de los participantes de nueve características, incluyendo atractivo, sabor, suavidad y atributos de personas que fuman la marca.

Resultados. Los paquetes de marca con sabor se calificaron como más atractivos, de mejor sabor y más suaves que los paquetes simples con sabores y descriptores. En comparación con los paquetes simples con sabores con descriptores, los mismos paquetes sin descriptores fueron calificados de manera menos positiva en ocho de las nueve características. En comparación con los no fumadores no susceptibles, los no fumadores susceptibles calificaron los paquetes con sabor de forma más positiva en ocho de las nueve características. Los paquetes delgados fueron clasificados más positivamente que los paquetes regulares en ocho de las nueve características.

Conclusiones. Los paquetes delgados y las marcas que destacan los sabores del tabaco parecen aumentar las percepciones positivas de los productos de tabaco. Prohibir los sabores del tabaco y los paquetes delgados puede reducir el atractivo del tabaco para las jóvenes brasileñas, así como para otras poblaciones vulnerables.

Tabaco; embalaje de productos; aromatizantes; mujeres; política de salud; Brasil.
RESUMO

\section{Sabores do cigarro, forma do pacote e percepções da marca do cigarro: um experimento entre mulheres jovens brasileiras}

Palavras-chave
Objetivo: Em 2012, uma nova regulamentação brasileira proibiu o uso de aditivos aromáticos nos produtos tabagísticos. Para entender melhor o impacto potencial desta regulação, este estudo examinou como a propaganda de aroma em embalagens de cigarros influencia a percepção das brasileiras jovens sobre a marca do produto.

Método: Estudo transversal em que 640 brasileiras (168 fumantes e 458 não fumantes) avaliaram online, uma entre três das seguintes características de 10 pacotes de cigarros: 1) embalagem com a imagem da marca; 2) pacotes com o mesmo tamanho, formato e descrição das características do produto 1, mas sem marca (havia apenas a descrição do produto) e, 3) embalagens nas condições 2 , mas sem a descrição do produto (embalagem em branco). $\mathrm{O}$ modelo de regressão linear misto foi utilizado para determinar associações das características da embalagem do cigarro (Ex: situação experimental, descrição de aroma versus não, pacotes finos versus não) com as avaliações das participantes para nove características do produto, incluindo a apelação, aroma, suavidade e atributos de quem fuma certa marca.

Resultados: Pacotes aromatizados de marca foram classificados como mais atraentes, com melhor sabor e suavidade em relação aos que tinham simples descrição do produto. Os pacotes descritos como aromatizados comparados ao mesmo produto sem descrição obtiveram menores escores para oito dentre nove características avaliadas. Em comparação as não fumantes sem suscetibilidade ao tabagismo, as que eram suscetíveis classificaram produtos aromatizados mais positivamente em oito de suas nove características. As embalagens finas receberam julgamento mais positivo do que as com espessura regular para oito dentre nove itens analisados.

Conclusões: Pacotes finos e marcas que destacam os aromas do tabaco parecem aumentar a percepção positiva deste produto. Proibir a aromatização do tabaco e a oferta de pacotes finos de cigarros reduzem o apelo de fumar entre brasileiras jovens, bem como para outros grupos vulneráveis.

Tabaco; embalagem de produtos; aromatizantes; mulheres; política de saúde; Brasil. 